\title{
Mixotrophic haptophytes are key bacterial grazers in oligotrophic coastal waters
}

\author{
Fernando Unrein ${ }^{1}$, Josep M Gasol, Fabrice Not $^{2}$, Irene Forn and Ramon Massana \\ Departament de Biologia Marina i Oceanografia, Institut de Ciències del Mar, CSIC, \\ Passeig Marítim de la Barceloneta 37-49, Barcelona, Catalonia, Spain
}

\begin{abstract}
Grazing rate estimates indicate that approximately half of the bacterivory in oligotrophic oceans is due to mixotrophic flagellates (MFs). However, most estimations have considered algae as a single group. Here we aimed at opening the black-box of the phytoflagellates (PFs) $<20 \mu \mathrm{m}$. Haptophytes, chlorophytes, cryptophytes and pigmented dinoflagellates were identified using fluorescent in situ hybridization or by standard 4',6-diamidino-2-phenylindole staining. Their fluctuations in abundance, cell size, biomass and bacterivory rates were measured through an annual cycle in an oligotrophic coastal system. On average, we were able to assign to these groups: $37 \%$ of the total pico-PFs and $65 \%$ of the nano-PFs composition. Chlorophytes were mostly picoplanktonic and they never ingested fluorescently labeled bacteria. About $50 \%$ of the PF $<20 \mu \mathrm{m}$ biomass was represented by mixotrophic algae. Pigmented dinoflagellates were the least abundant group with little impact on bacterioplankton. Cryptophytes were quantitatively important during the coldest periods and explained about $4 \%$ of total bacterivory. Haptophytes were the most important mixotrophic group: (i) they were mostly represented by cells $3-5 \mu \mathrm{m}$ in size present year-round; (ii) cell-specific grazing rates were comparable to those of other bacterivorous non-photosynthetic organisms, regardless of the in situ nutrient availability conditions; (iii) these organisms could acquire a significant portion of their carbon by ingesting bacteria; and (iv) haptophytes explained on average $40 \%$ of the bacterivory exerted by MFs and were responsible for $9-27 \%$ of total bacterivory at this site. Our results, when considered alongside the widespread distribution of haptophytes in the ocean, indicate that they have a key role as bacterivores in marine ecosystems.

The ISME Journal (2014) 8, 164-176; doi:10.1038/ismej.2013.132; published online 8 August 2013

Subject Category: Microbial ecology and functional diversity of natural habitats

Keywords: mixotrophic; haptophytes; cryptophytes; oligotrophic coastal seawater
\end{abstract}

\section{Introduction}

Mixotrophy in algae, defined as the combination of phagotrophy and phototrophy in a single cell (sensu Sanders, 1991), is widespread among algal groups containing flagellated species (Bird and Kalff, 1986; Tranvik et al., 1989; Nygaard and Tobiesen, 1993; Stoecker, 1999). The mixotrophic mode of nutrition is considered to be particularly beneficial when inorganic nutrients are limiting (Nygaard and Tobiesen, 1993; Rothhaupt, 1996;

Correspondence: F Unrein, Instituto de Investigaciones Biotecnológicas-Instituto Tecnológico de Chascomús (IIB-INTECH), UNSAM-CONICET, Camino de Circunvalación Laguna $\mathrm{Km}$ 8.200, (7130) Chascomús, Buenos Aires, Argentina.

E-mail: funrein@intech.gov.ar

${ }^{1}$ Present address: Instituto de Investigaciones BiotecnológicasInstituto Tecnológico de Chascomús (IIB-INTECH), UNSAMCONICET, Camino de Circunvalación Laguna Km 8.200, (7130) Chascomús, Buenos Aires, Argentina

${ }^{2}$ Present address: Station Biologique de Roscoff, UMR7144, Centre National de la Recherche Scientifique (CNRS), et Université Pierre et Marie Curie (UPMC), Place George Teissier, Roscoff 29680, France

Received 14 March 2013; revised 13 June 2013; accepted 1 July 2013; published online 8 August 2013
Flöder et al., 2006). It has been demonstrated that mixotrophic algae, in particular those $<5 \mu \mathrm{m}$ in size, are major grazers of picoplankton in oligotrophic marine systems, being regularly responsible for $>50 \%$ of the total bacterivory (Unrein et al., 2007; Zubkov and Tarran, 2008; Hartmann et al., 2012). These estimates were obtained using completely different methodologies, strongly suggesting a global significance of mixotrophy in all marine systems (Gasol et al., 2008).

Although it has been shown that marine mixotrophic flagellates (MFs) belong to different algal lineages (haptophytes, cryptophytes, dinoflagellates, and so on), most grazing rates estimations have considered the mixotrophic algae as a single group. At most, they were divided into different cell size categories (Zubkov et al., 2001; Chan et al., 2009; Tsai et al., 2011) while very few studies have attempted to discriminate them by taxonomic affiliation (but see Havskum and Riemann, 1996). This is essentially because of the difficulty of determining the taxonomic identity of tiny organisms and simultaneously estimate their in situ grazing rates. As a consequence, MFs are usually regarded as a 'black-box'. 
In addition, studies of the impact of MF in marine systems are generally restricted to short time periods, usually days or weeks depending on the duration of the cruise, precluding any inference on seasonal changes. Contrary to freshwater environments, where mixotrophic activity usually fluctuates during the year because of changes in MF composition (Sanders et al., 1989; Hitchman and Jones, 2000; Pålsson and Granéli, 2003), the only seasonal study performed so far in a marine system reported a constant impact of MF throughout the year (Unrein et al., 2007). We hypothesized that this pattern could be explained by the stability of MF community structure (for example, with dominance of a single taxa) throughout the annual cycle. However, assessment of the changes in grazing impact of each marine MF along an annual cycle has not yet been attempted.

Environmental surveys using molecular approaches have revealed a high contribution and diversity of haptophytes (Prymnesiophyceae) among the small photosynthetic eukaryotes in marine (Fuller et al., 2006; Liu et al., 2009; Cuvelier et al., 2010; Shi et al., 2011; Treusch et al., 2012) but also in some freshwater ecosystems (Bielewicz et al., 2011; Kong et al., 2012). In addition, Jardillier et al. (2010) estimated that haptophytes are responsible for a very significant percentage of the total $\mathrm{CO}_{2}$ fixation in the tropical and subtropical Northeast Atlantic Ocean. Frias-Lopez et al. (2009) identified mixotrophic haptophytes as one of the most important picocyanobacterial predators in the sea, although the methodology they used did not allow to obtain grazing rates estimations. The high diversity, abundance and wide distribution of haptophytes in the oceans, together with their capability to ingest organic particles, suggest they can have a key role as grazers in the microbial food web.

In a previous study we reported the grazing impact of heterotrophic flagellates (HFs) and phytoflagellates (PFs) on bacteria in a coastal oligotrophic site (Unrein et al., 2007). Mixotrophic impact resulted to be high all year round, representing between 35\% and $65 \%$ of the total flagellate bacterivory (Unrein et al., 2007). Here we aimed at opening the black-box of the mixotrophic pico- and nanophytoplankton according to their taxonomic affiliation. The main phytoplankton taxa smaller than $20 \mu \mathrm{m}$ were identified and quantified by using specific probes and fluorescent in situ hybridization (FISH; haptophytes and chlorophytes) or by their distinctive autofluorescence and general morphology on standard $\quad 4^{\prime}, 6$-diamidino-2-phenylindole (DAPI)stained samples (cryptophytes and pigmented dinoflagellates). Their fluctuations in abundance, cell size, biomass and bacterivory rates were measured through an annual cycle and we combined short-term grazing experiments using fluorescently labeled bacteria (FLBs) with epifluorescence identification to estimate the grazing rates of the specific MF. Our results identified the MF groups that are responsible for most of the bacterivory in this oligotrophic coastal marine system.

\section{Materials and methods}

\section{Study area and sampling}

Samples were taken at the Blanes Bay Microbial Observatory on the Catalan coast (BBMO, NW Mediterranean $41^{\circ} 40^{\prime} \mathrm{N}, 2^{\circ} 48^{\prime} \mathrm{E}$ ). Extensive previous information exists about the microbial ecology and biogeochemistry of this site (for example, Schauer et al., 2003; Unrein et al., 2007; Alonso-Sáez et al., 2008). For the time series, surface water samples were collected once a month between March 2003 and March 2004. Sampling details and the abiotic variables measured during this period were described in Unrein et al. (2007) and are summarized in Supplementary Table 1. Some of these data have also been presented in previous articles (Unrein et al., 2007; Vázquez-Domínguez et al., 2007; Alonso-Sáez et al., 2008).

\section{Short-term grazing experiments}

Bacterivory rates were determined by ingestion of FLBs. The FLBs were prepared from a Brevundimonas diminuta (syn. Pseudomonas diminuta) strain obtained from the Spanish Type Culture Collection (Burjassot, València, Spain). B. diminuta has been used because of their small size $\left(0.065 \mu \mathrm{m}^{3}\right)$ comparable to that of the indigenous bacterial populations. FLBs were prepared following Sherr et al. (1987).

Bacterivory rates were estimated for three size categories $(<3,3-5$ and $5-20 \mu \mathrm{m})$ of HFs and phototrophic flagellates and for four different algal groups: cryptophytes, haptophytes (three size categories), pigmented dinoflagellates (two size categories) and chlorophytes (three size categories plus genus Micromonas). Results of total $\mathrm{HF}$ and $\mathrm{PF}$ abundance and total ingestion rates were already published in Unrein et al. (2007), and are used here only to compare with the grazing rates and abundances of each algal group.

The experimental conditions were fully described in Unrein et al. (2007). Briefly, seawater was gently filtered through a $100 \mu \mathrm{m}$ net before adding FLBs to $10-30 \%$ of natural bacteria abundance. Preparation of the FLB tracers and estimation of bacteria and FLB abundances were done as explained in Unrein et al. (2007). Experiments were run in triplicates and incubated under in situ temperature. A fixed light intensity of $200 \mu \mathrm{mol} \mathrm{m}{ }^{-2} \mathrm{~s}^{-1}$ corresponding to mean light intensity in the water column at the time of sampling (average $=275 \mu \mathrm{mol} \mathrm{m}^{-2} \mathrm{~s}^{-1}, \quad$ s.e. $=66$, $n=11$ ) was used in all the experiments. Samples to estimate ingestion of FLB were taken at the beginning (T0) and after $40 \mathrm{~min}$ of incubation (T40). Two types of samples were taken at each time: one fixed with glutaraldehyde to estimate grazing by total HF, total PF, cryptophytes and pigmented dinoflagellates using standard DAPIstained samples, and another fixed with formaldehyde to estimate grazing by haptophytes and 
chlorophytes using specific probes and FISH (see below for further explanation).

A volume of $120 \mathrm{ml}$ of sample from each replicate bottle were fixed with $120 \mathrm{ml}$ of cold glutaraldehyde ( $2 \%$ final concentration). Between 70 and $100 \mathrm{ml}$ of fixed water were filtered through a $0.6 \mu \mathrm{m}$ pore size polycarbonate black filter (Poretics, Minnetonka, MN, USA) and stained with DAPI (Porter and Feig, 1980). The FLB ingestion of cells $\mathrm{PF}<3 \mu \mathrm{m}$ and 3-5 $\mu \mathrm{m}$ were observed in a Olympus BX61 epifluorescence microscope (Tokyo, Japan) in this filter. The remaining volume ( $\mathrm{ca} 120-140 \mathrm{ml}$ ) was filtered through a $3 \mu \mathrm{m}$ polycarbonate black filter to observe PF 5-20 $\mu \mathrm{m}$, cryptophytes and pigmented dinoflagellates. PFs were those cells showing red or orange plastidic structures under blue light excitation (see Figure 4 below). Sometimes, we observed HF with pigmented prey, but without plastidic structures, and these were excluded from our analysis. Cryptophytes were recognized by their yellow-orange fluorescence under blue light excitation and bright orange fluorescence under green light excitation because of the presence of phycobilins (MacIsaac and Stoeckner, 1993). Pigmented dinoflagellates were distinguished by the presence of the nucleus with condensed chromosomes and by their general morphology.

Aliquots fixed with freshly prepared formaldehyde (3.7\% final concentration) were filtered on $0.6 \mu \mathrm{m}$ pore size polycarbonate filters and kept frozen until processed. We used the same volume of sample and fixatives as for glutaraldehyde samples. These filters were used to estimate FLB ingestion by haptophytes and chlorophytes. Haptophytes were detected by FISH using the CY3-labeled probe PRYM02 (Simon et al., 2000) supplied by Thermo Fisher Scientific (Ulm, Germany). For FISH, we followed the protocol and conditions detailed previously (Pernthaler et al., 2001; Massana et al., 2006). Briefly, filter portions with protist cells were hybridized for $3 \mathrm{~h}$ at $46^{\circ} \mathrm{C}$ in the appropriate buffer (with $30 \%$ formamide), washed at $48^{\circ} \mathrm{C}$ in a second buffer, counter-stained with DAPI and mounted on a slide. Cells were then immediately observed by epifluorescence microscopy under green light excitation. Chlorophytes and the genus Micromonas (Mamiellophyceae, Prasinophyceae and Chlorophyta) were enumerated by tyramide signal amplification-FISH (TSA-FISH), also named catalyzed reporter deposition-FISH, using the probes CHLO02 and MICRO01, respectively (Simon et al., 2000; Not et al., 2004). Probes labeled with a horseradish peroxidase enzyme were also provided by Thermo Fisher Scientific. For TSA-FISH, we followed the protocol and conditions detailed in Not et al. (2002). Briefly, filter pieces were hybridized overnight at $35{ }^{\circ} \mathrm{C}$ in a buffer containing $30 \%$ formamide. After hybridization, the filters were washed in a second buffer at $37^{\circ}$, the signal was amplified with Alexa 546-labeled tyramide and counter-stained with DAPI. Filter pieces were mounted on a slide and observed by epifluorescence microscopy under green light excitation. The unique modification of the original protocol proposed by Not et al. (2002) was that we used Alexa 546-Tyramide (instead of fluorescein isothiocyanate-Tyramide) to be able to differentiate the FISH signal (bright orange fluorescence under green light excitation) from the FLB signal (yellow-green when excited with blue light). A comparison of both protocols, FISH vs TSA-FISH, performed in some selected samples with different probes indicated that both methodologies offered the same results. We had to use TSA-FISH to properly observe the very small chlorophytes; whereas for haptophytes we decided to use monolabeled FISH probes, as the procedure is easier and faster than for TSA-FISH.

The grazing rates on bacteria were determined from the uptake of FLB by the different groups of flagellates. Ingestion rates (FLB cells ${ }^{-1} \mathrm{~h}^{-1}$ ) were calculated from the number of ingested FLB at T40 after subtracting the value at T0. This incubation time was chosen since FLB ingestion reached a plateau by 45 min (Unrein et al., 2007). The 95\% confidence intervals of ingestion estimates were calculated as follows:

$$
P-1.96[P(1-P) / n]^{1 / 2}
$$

where $P$ is the average number of FLB inside a cell, and $n$ the number of cells inspected. Uptake was considered significant when the 95\% confidence intervals of the T0 and T40 estimates did not overlap (Rice, 1988, cited in Havskum and Riemann, 1996).

A mean of $c a 200$ haptophytes, 90 cryptophytes and 100 chlorophytes cells were inspected on each filter. Considering that each experiment was run in triplicate and was sampled twice (T0 and T40), thus a total of 300-1000 phototrophic flagellates of each group were examined for FLB ingestion in each experiment. Ingestion rates by cryptophytes were significant in 11 out of 12 samples, haptophytes in all the experiments, whereas bacterivory by pigmented dinoflagellates was estimated only once (December) because of their low abundance throughout the year. At that time, 370 dinoflagellates cells were inspected for FLB ingestion. Chlorophytes never showed any FLB ingestion.

Clearance rates (CRs; nl cells ${ }^{-1} \mathrm{~h}^{-1}$ ) for each MF group were calculated by dividing the ingestion rate by the FLB concentration. Cell-specific grazing rates (CSGRs; bact. cells ${ }^{-1} \mathrm{~h}^{-1}$ ) were calculated by multiplying CRs by the bacterial abundance (cells $\mathrm{ml}^{-1}$ ). Grazing impact (bact. $\mathrm{ml}^{-1} \mathrm{~h}^{-1}$ ) of each MF group was estimated by multiplying the CSGR by the flagellate abundance. For pigmented dinoflagellates, we multiplied the CSGR estimated in December by the abundance observed at each date. Bacterial turnover rates $\left(\%\right.$ day $\left.^{-1}\right)$ were estimated by expressing the grazing impact as a percentage of the bacterial abundance. The grazing contribution of each group was estimated by expressing the 
grazing impact of each MF group as a percentage of the total mixotrophic and total protist grazing (data published in Unrein et al., 2007). The cellspecific ingestion rate in percentage of the cell carbon per day $\left(\%\right.$ day $\left.^{-1}\right)$, was calculated for each MF group by dividing their respective CSGRs expressed in biomass of bacteria ( $\mu \mathrm{g} \mathrm{C}$ bact. cells ${ }^{-1}$ day $^{-1}$ ) by the mean flagellate biomass ( $\mu \mathrm{g} \mathrm{C}$ cells ${ }^{-1}$ ).

\section{Bacterial and PFs biomass}

Bacterial cell size was estimated by flow cytometry, using the average fluorescence (FL1) of the SYTO-13 stained bacteria and YG Polysciences beads according the Gasol and del Giorgio (2000) equation:

$$
\mu \mathrm{m}^{3} \text { cell }^{-1}=0.0075+0.11 \times\left(\mathrm{FL}_{1} 1_{\text {bacteria }} / \mathrm{FL}_{\text {Beads }}\right)
$$

Bacterial biomass was calculated by using the carbon-to-volume equation derived by Norland (1993) from the data of Simon and Azam (1989):

$$
\operatorname{pgCcell}{ }^{-1}=0.12 \times\left(\mu \mathrm{m}^{3} \text { cell }^{-1}\right)^{0.7}
$$

PF cell size was estimated by image analysis using the Image Pro Plus software analyzer (Media Cybernetics Inc., Bethesda, MD, USA). Cell volume was estimated from length and width measurements (Sun and Liu, 2003) assuming a prolate spheroid for haptophytes, chlorophytes, dinoflagellates and most cryptophyte cells. For some cryptophytes cells, a cone plus half a sphere equation was applied. Cell volume was converted into biomass using the carbon-to-volume equation published by Menden-Deuer and Lessard (2000) for protist plankton:

$$
\operatorname{pgCcell}{ }^{-1}=0.216 \times\left(\mu \mathrm{m}^{3} \mathrm{cell}^{-1}\right)^{0.939}
$$

Mean cell volume was estimated for each size category of each PF group, by measuring at least 20 individuals at every date, except for the less abundant groups (that is, haptophytes $<3 \mu \mathrm{m}$, dinoflagellates $<10 \mu \mathrm{m}$ and dinoflagellates $>10 \mu \mathrm{m})$. In fact, the number of measured cells in each group was proportional to its in situ abundance. For groups exhibiting size changes along the study (that is, cryptophytes), we used the per-date cell volume to estimate the biomass at each date, whereas for those without an evident size variation, we used the average value obtained from the entire data set.

'Unknown PF' abundance was estimated for each size category $(<3,3-5$ and $5-20 \mu \mathrm{m})$, as the difference between PF abundance from Unrein et al. (2007) and the sum of the four groups here identified (haptophytes, chlorophytes, dinoflagellates and cryptophytes). Cell volume was calculated assuming an equivalent spherical diameter of 2 , 4 and $7 \mu \mathrm{m}$ for each size class, respectively. Biomass was estimated with Equation 4.
Statistical analyses

We used non-parametric Spearman's correlations coefficients $(\rho)$ to test for the significance of the associations between grazing estimates and environmental parameters. The coefficient of variation for each variable was computed as the percentage of s.d. with respect to the mean value.

\section{Results}

In situ conditions

Water temperature ranged between 11 and $25^{\circ} \mathrm{C}$ following the seasonal variation. A weak stratification was observed during June and July, whereas during the rest of the year the temperature was similar throughout the $20 \mathrm{~m}$ depth of the water column. The photic layer generally reached the bottom. Nutrient concentrations, especially soluble reactive phosphorus, were low $(0.12-0.24 \mu \mathrm{M})$ throughout the study period (Supplementary Table 1). Chl a concentration fluctuated around $1 \mu \mathrm{gl}^{-1}$ (Supplementary Table 1) with maximum concentration at the beginning of winter $\left(3.93 \mu \mathrm{gl}^{-1}\right)$ and minimal in summer $\left(0.25 \mu \mathrm{gl}^{-1}\right)$. The highest bacterial abundance concurred with the peaks in Chl $a$ (around $1.3 \times 10^{6}$ bact. $\mathrm{ml}^{-1}$ ).

\section{Phytoplankton composition (cells $<20 \mu \mathrm{m}$ )}

Four groups of algae were identified in the present survey. Chlorophytes and haptophytes were the only two algal groups with picoplanktonic-size representatives $(<3 \mu \mathrm{m})$, whereas cryptophytes and pigmented dinoflagellates were exclusively nanoplanktonic ( $>3 \mu \mathrm{m}$; Figure 1$)$. The main morphometric parameters for the algal groups considered and the different size classes are presented in Supplementary Table 2.

Chlorophytes (targeted by the CHLO02 probe) were mostly represented by small cells (Figure 1). The average biovolume of chlorophytes was $21 \mu \mathrm{m}^{3}$. On average, $77 \%$ of the cells were $<3 \mu \mathrm{m}$ in size. This group showed a marked variability along the year (coefficient of variation $=122 \%$ ) with highest abundances observed at the beginning and at the end of winter $\left(1.1 \times 10^{4} \mathrm{cells} \mathrm{ml}^{-1}\right)$, and with the lowest values during the warmest season (150 cells ml ${ }^{-1}$, Figure 2a). Micromonas pusilla (targeted by probe MICRO01) represented on average $90 \%$ of the cells $<3 \mu \mathrm{m}$ detected by CHLO02 (Figure 2c). Chlorophytes $3-5 \mu \mathrm{m}$ in size reached $\sim 1100$ cells $\mathrm{ml}^{-1}$ as maximum abundance during the winter season, while they never exceeded 130 cells $\mathrm{ml}^{-1}$ during summer (Figure 2b). Chlorophytes $5-20 \mu \mathrm{m}$ in size reached a maximum of 200 cells $\mathrm{ml}^{-1}$ in December. This algal group explained on average $35 \%$ and $20 \%$ of the picoplankton (PF $<3 \mu \mathrm{m}$ ) and nanoplankton (PF $3-20 \mu \mathrm{m})$ abundances respectively, with the 


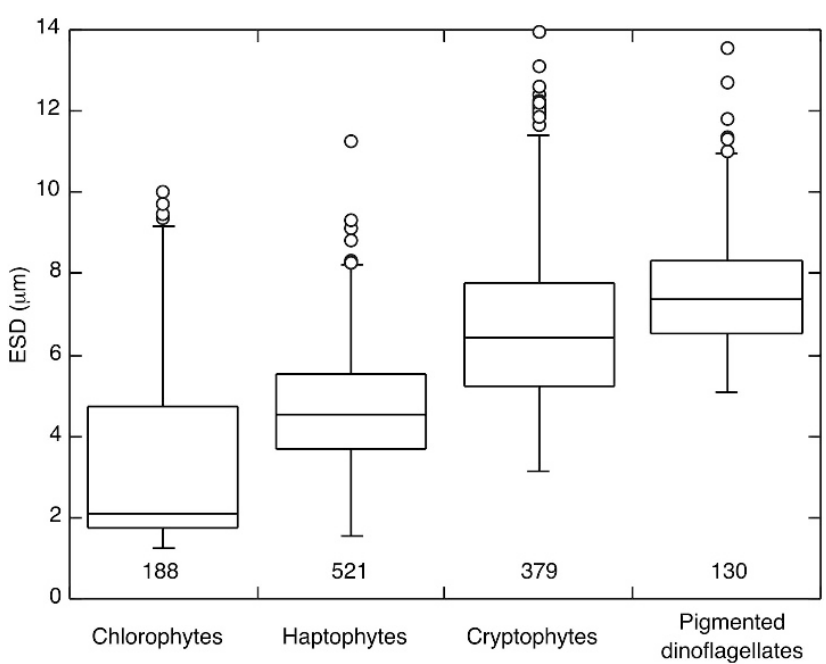

Figure 1 Box plot summary of the ESD (equivalent spherical diameter) distributions for the main groups of PFs in Blanes Bay. Boxes include $50 \%$ of data with the median displayed as a line. Bars indicate the range, excluding the outlier values that are represented by open circles. The number of cells measured for each group is indicated below each box. highest contribution in autumn and spring (Figure 2).

Haptophytes (targeted with the PRYM02 probe) were dominated by small nanoplanktonic cells (Figure 1) with an average biovolume of $69 \mu \mathrm{m}^{3}$. On average, $73 \%$ of the haptophytes were $3-5 \mu \mathrm{m}$ in size, $21 \%$ of the cells measured $5-20 \mu \mathrm{m}$ and only $6 \%$ were $<3 \mu \mathrm{m}$. Abundances of picoplanktonic haptophytes fluctuated around 40 cells $\mathrm{ml}^{-1}$, whereas nanoplanktonic haptophyte abundance was always higher than 300 cells ml ${ }^{-1}$ (average: 804 cells $\mathrm{ml}^{-1}$ ) with relatively modest variation along the study period (coefficient of variation $=53 \%$ ) (Figures $2 \mathrm{a}$ and $\mathrm{b}$ ). Haptophytes were only $2 \%$ of the PF $<3 \mu \mathrm{m}$, while they accounted for $\sim 40 \%$ of the total PF $3-20 \mu \mathrm{m}$ in size, being the most abundant group among the nanoplankton, with maximum contributions (up to $64 \%$ ) observed during the summer (Figures 2c and d).

Cryptophytes were substantially larger than haptophytes and chlorophytes (Figure 1). The cell volume of cryptophytes varied seasonally between $>300 \mu \mathrm{m}^{3}$
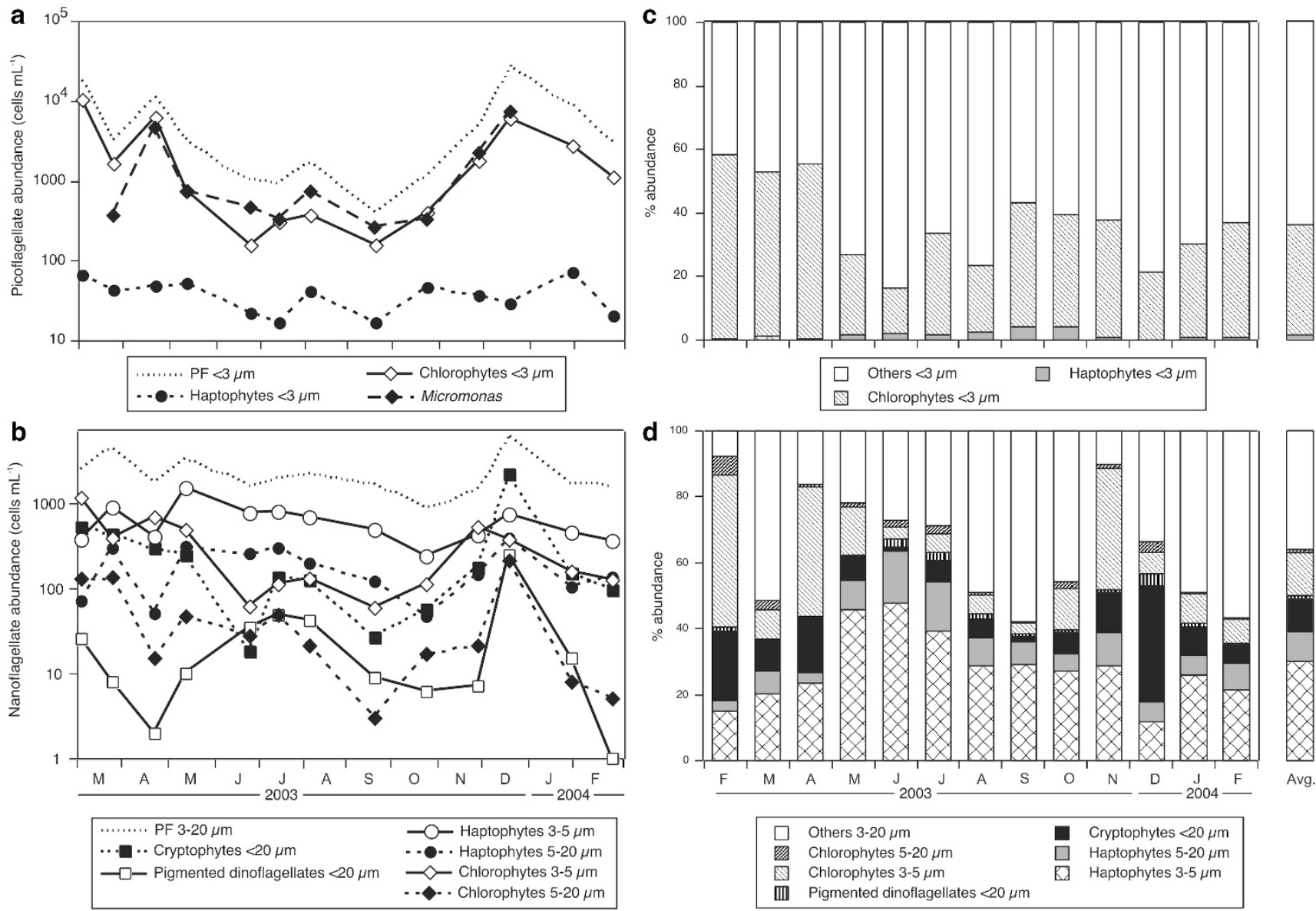

Figure 2 (a) Temporal fluctuation in abundance of chlorophytes $<3 \mu \mathrm{m}$ (targeted with probe CHLO02), Micromonas (targeted with probe MICRO01) and haptophytes $<3 \mu \mathrm{m}$ (targeted with probe PRYM02). PF $<3 \mu \mathrm{m}$ represent the total picoflagellate algae enumerated by DAPI. (b) Temporal fluctuation in abundance of haptophytes 3-20 $\mu \mathrm{m}$ (targeted with probe PRYM02), chlorophytes 3-20 $\mu \mathrm{m}$ (targeted with probe CHLO02), cryptophytes $<20 \mu \mathrm{m}$ and pigmented dinoflagellates $<20 \mu \mathrm{m}$. PF $3-20 \mu \mathrm{m}$ represent the total nanoflagellate algae enumerated by DAPI. (c) Proportion of total PFs $<3 \mu \mathrm{m}$ and (d) $3-20 \mu \mathrm{m}$ abundance explained by each of the four algal groups throughout the year. Avg., annual average. 
in winter-spring to $<180 \mu \mathrm{m}^{3}$ in summer-autumn (Supplementary Figure 1). Cryptophytes showed a similar temporal pattern to that observed for nanoplanktonic chlorophytes (Figure 2b), although with higher variation along the year (coefficient of variation $=167 \%$ ). Abundances (log transformed) of both groups were highly correlated $(r=0.84 ; P<0.001)$, suggesting they responded similarly to environmental fluctuations. Cryptophytes averaged 342 cells $\mathrm{ml}^{-1}$, with a maximum value of 2173 cells $\mathrm{ml}^{-1}$ recorded on December 2003. This group accounted for about $13 \%$ of the total PF $3-20 \mu \mathrm{m}$ abundance (Figure 2d).

Pigmented dinoflagellates $<20 \mu \mathrm{m}$ were the least abundant group and were represented by relatively large cells (Figure 1). The average biovolume was $266 \mu \mathrm{m}^{3}$. A clear seasonal trend was observed with a maximal abundance during early winter (December) and a secondary peak in summer (Figure 2b). They contributed to ca $1 \%$ of the total PF $3-20 \mu \mathrm{m}$ abundance (Figure 2d).

Overall, chlorophytes and haptophytes explained on average $37 \%$ of the total $\mathrm{PF}<3 \mu \mathrm{m}$ abundance (Figure 2c), while the four groups of nano-PFs explained on average $65 \%$ of the total 3-20 $\mu \mathrm{m}$ PF abundance (Figure 2d).

In terms of biomass, and considering all the groups of algae and size classes together, we were able to identify between $44 \%$ and $77 \%$ (average $63 \%$ ) of the $\mathrm{PF}<20 \mu \mathrm{m}$ biomass (Figure 3). Haptophytes accounted for most biomass during the warmer months (up to $50 \%$ ), whereas chlorophytes and cryptophytes shared the dominance from the beginning of winter to middle spring (Figure 3). On average, at least $49 \%$ of the total PF $<20 \mu \mathrm{m}$ biomass retrieved on our analyses belonged to algal groups with mixotrophic representatives (see below 'Bacterivorous algal groups').

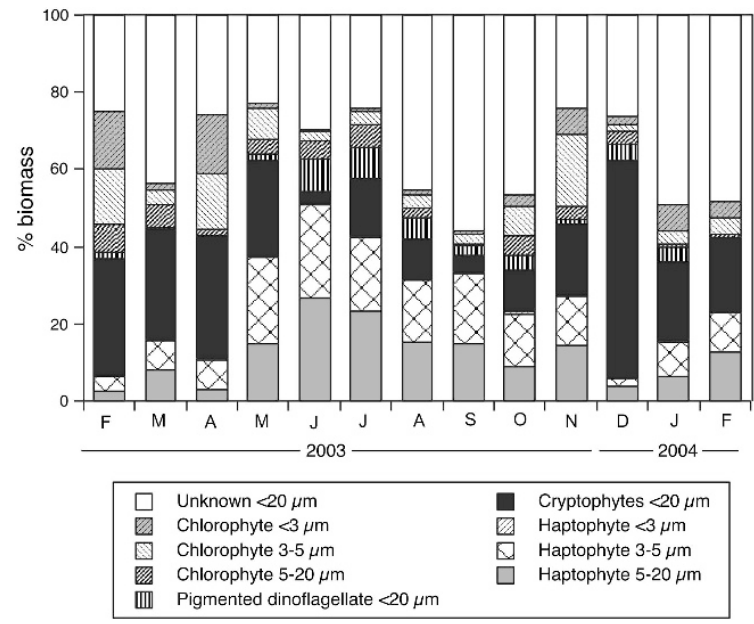

Figure 3 Contribution of each algal group to the biomass of total $\mathrm{PF}<20 \mu \mathrm{m}$ throughout the year. Avg., annual average.
Taxa-specific grazing characteristics of the $M F$ assemblages

Grazing experiments performed with FLBs revealed that haptophytes, cryptophytes and pigmented dinoflagellates were able to ingest bacteria in our samples. Dinoflagellates (and sometimes also large haptophytes) were frequently observed with ingested cryptophytes and/or haptophytes (Figure 4). Other phagotrophic PFs, like Dinobryon faculiferum (Chrysophyceae) and Pseudopedinella sp. (Dictyochophyceae) were sporadically also
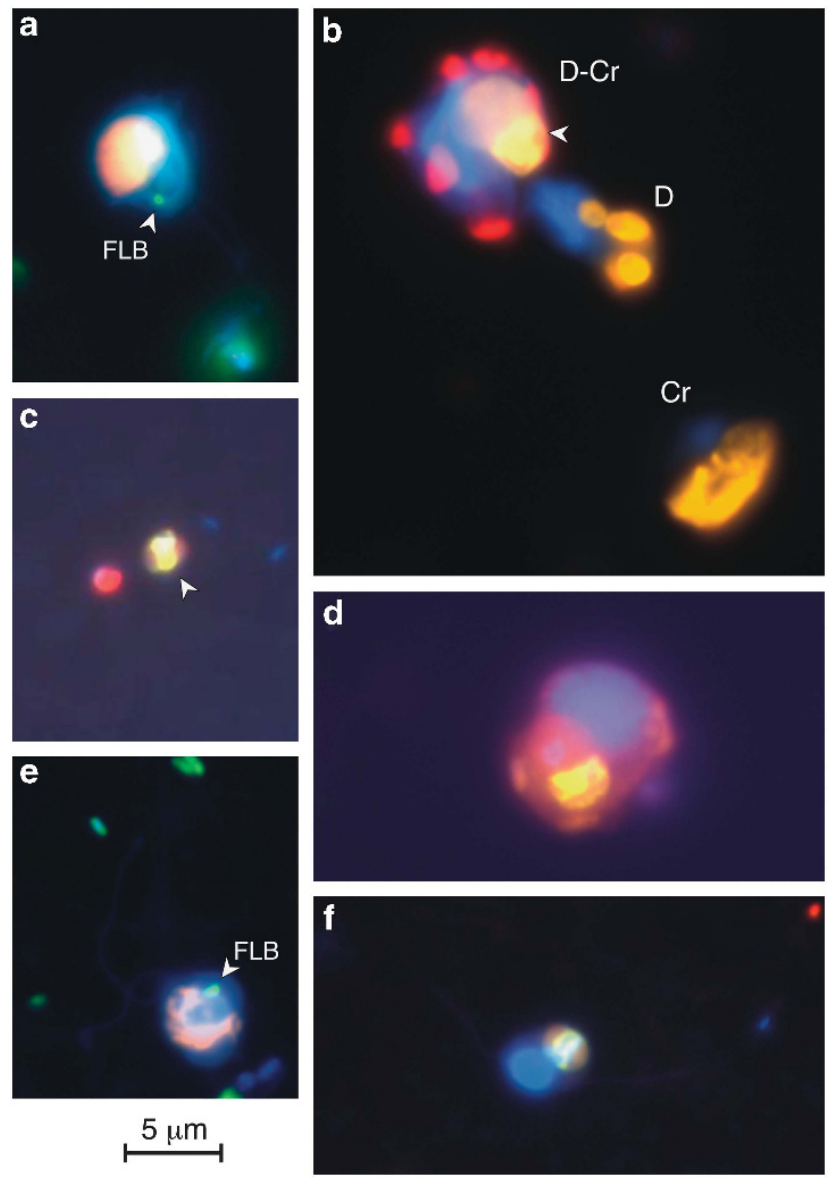

Figure 4 Epifluorescence micrographs of examples of the different mixotrophic groups. (a) Cryptophyte cell with an ingested FLBs. (b) Pigmented dinoflagellate with an ingested cryptophyte (D-Cr), pigmented dinoflagellate containing phycobilins pigments (D) and a cryptophyte cell (Cr). (c) Two picoplanktonic algae, the arrow indicates the haptophyte cell positively hybridized with the probe PRYM02. (d) Pigmented dinoflagellate with a haptophyte cell positively hybridized by FISH inside the food vacuole. (e) Haptophyte cell hybridized with the PRYM02 probe with an ingested FLB. (f) HF with an ingested haptophyte. Each color image is an overlay of three pictures (obtained in 8-bit grayscale) of the same cells observed under different wavelength excitations: UV radiation (showing the blue nucleus after DAPI staining), blue light excitation (red chloroplast and green FLB) and green light excitation (showing the chloroplasts of cryptophytes and dinoflagellates containing phycobilins in figures $\mathbf{a}, \mathbf{b}$, and the orange cytoplasm in haptophytes after FISH in figures $\mathbf{c}-\mathbf{f}$ ). Pictures were obtained under $\times 1000$ magnification; the same scale applies to all pictures. 
observed with ingested FLB, but in low abundance. Picoplanktonic haptophytes $(<3 \mu \mathrm{m})$ were also observed with ingested FLB, however, the relatively few positive cells recorded did not allow for a reliable measurement of grazing rates within this size fraction. Chlorophytes showed no ingestion of FLBs in any experiment.

CSGRs and CRs were slightly higher in larger organisms compared with smaller ones (Table 1). No clear seasonal trends were observed on CSGR for any group, and consequently higher grazing impacts were estimated during the periods of higher abundances: that is, haptophytes in summer, cryptophytes in winter and both groups in December 2003 (Figures 2 and 5). As a result of their usual low abundance, the grazing rates of pigmented dinoflagellates $<20 \mu \mathrm{m}$ could be estimated only on one date, corresponding to the algal bloom that occurred in December. The rate obtained was similar to those calculated for the other large mixotrophic algae (Table 1).

The grazing impacts (bact. $\mathrm{ml}^{-1} \mathrm{~h}^{-1}$ ) of haptophytes $3-5 \mu \mathrm{m}$ were on average two times higher than those observed for cryptophytes and haptophytes $5-20 \mu \mathrm{m}$ (Table 1). The contribution of haptophytes $3-5 \mu \mathrm{m}$ to the total mixotrophic grazing was very significant, reaching at times $74 \%$ (average $27 \%$ ) of the total grazing exerted by all mixotrophs (Figure 6). If we include all haptophytes (including all size classes), they were responsible for up to $89 \%$ (average $40 \%$ ) of the total grazing exerted by all mixotrophs (Table 1; Figure 6). Compared with the total grazing rates previously measured (Unrein et al., 2007 ), between $9 \%$ and $27 \%$ (average of $15 \%$ ) of the total bacterivory exerted by all bacterivorous protists $<20 \mu \mathrm{m}$ (heterotrophic and MFs, and ciliates) was performed by haptophytes. The contribution of cryptophytes and pigmented dinoflagellates to total mixotrophic grazing averaged $8 \%$ and $3 \%$, respectively. The cellspecific ingestion rate in percentage of the cell carbon per day $\left(\% \mathrm{day}^{-1}\right)$ was higher for the smallest mixotrophs (haptophytes $3-5 \mu \mathrm{m}$, between $1.9 \%$ and $15.5 \%$ ), whereas the lowest values corresponded to cryptophytes (between $0 \%$ and $4.1 \%$, Table 1 ).

It could a priori be expected that mixotrophy should be related to nutrient and light availability. Thus, we tested whether the group-specific patterns of CRs or CSGRs of the mixotrophs were related to these environmental variables (Supplementary Figure 2). The CRs and CSGRs of cryptophytes were significantly correlated with Secchi depth $(\rho=0.87$ and $\rho=0.80$, respectively; $N=12, P<0.05)$ and photoperiod $(\rho=0.84$ and $\rho=0.74$, respectively; $N=12, P<0.05$ ), and negatively with dissolved inorganic nitrogen concentration $(\rho=-0.74$ and $\rho=-0.64$, respectively; $N=12, P>0.05$ ). Haptophytes, analyzed either by size classes or pooling all haptophytes

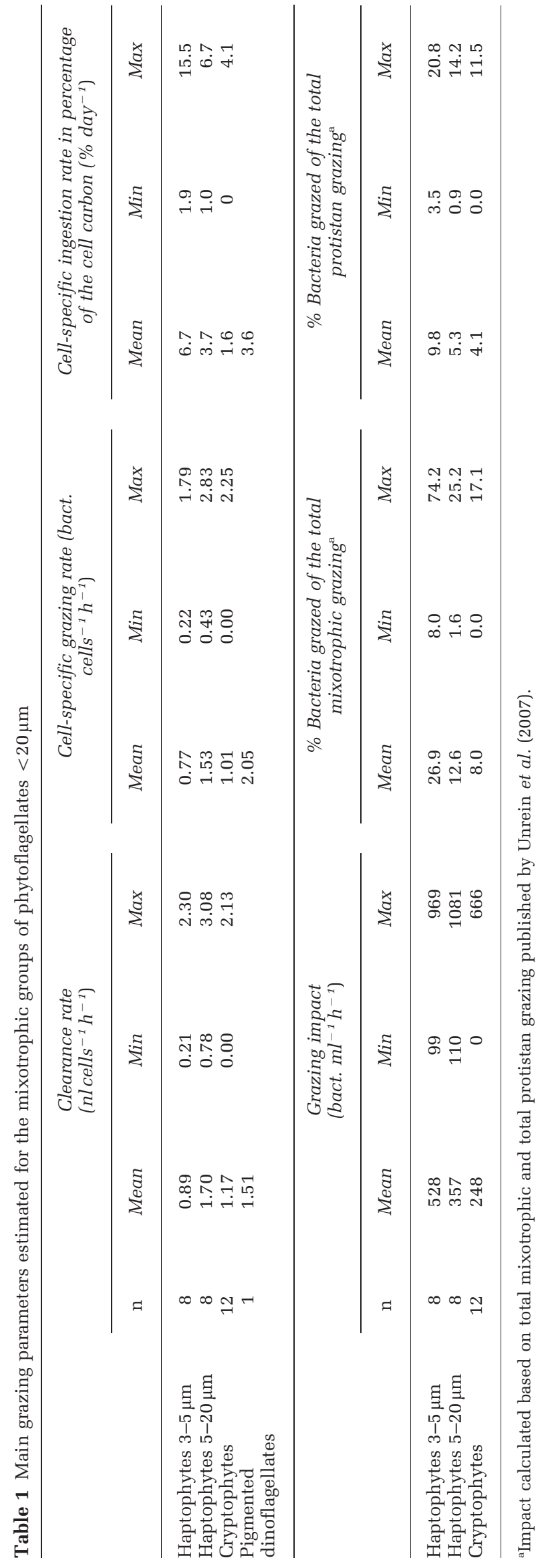




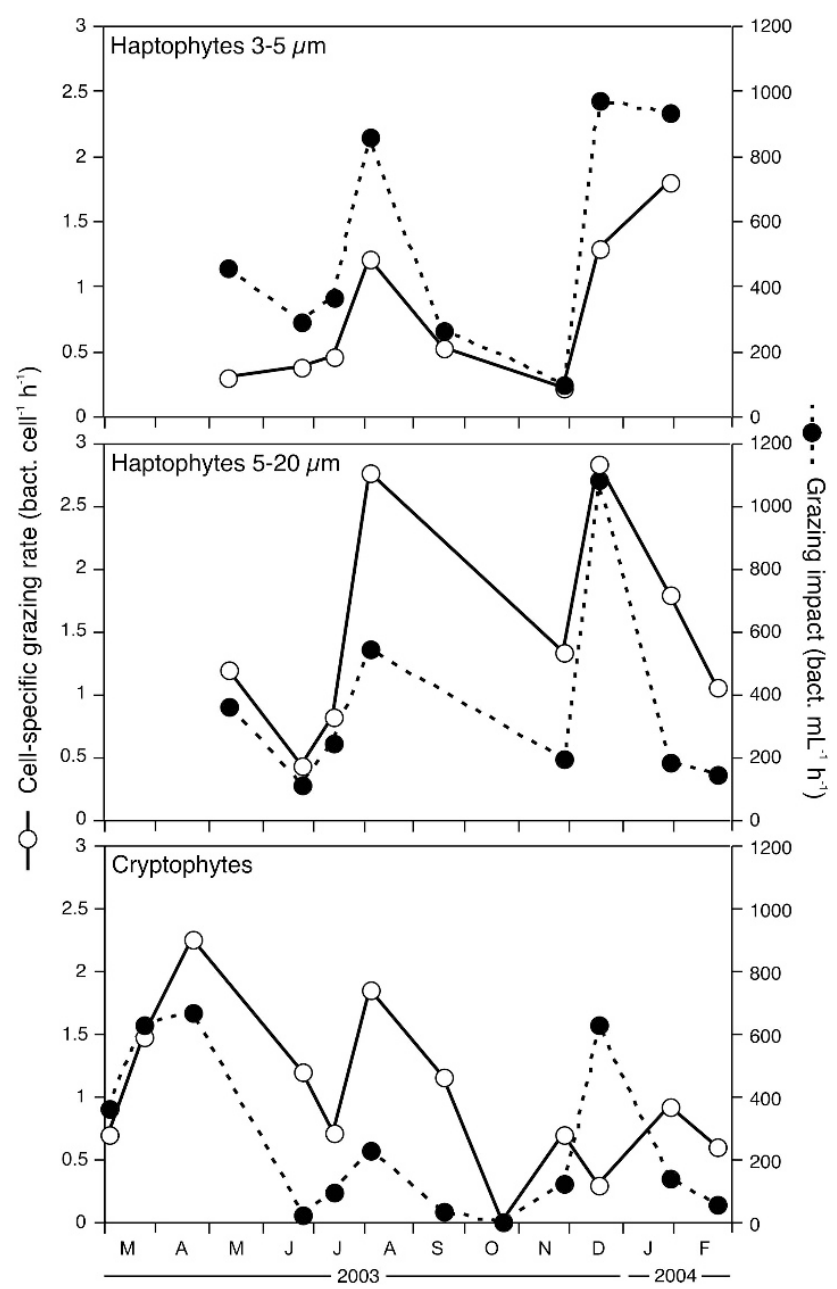

Figure 5 CSGR (bact. cells ${ }^{-1} \mathrm{~h}^{-1}$ ) and grazing impact (bact. $\mathrm{ml}^{-1} \mathrm{~h}^{-1}$ ) of the main mixotrophic groups along the year.

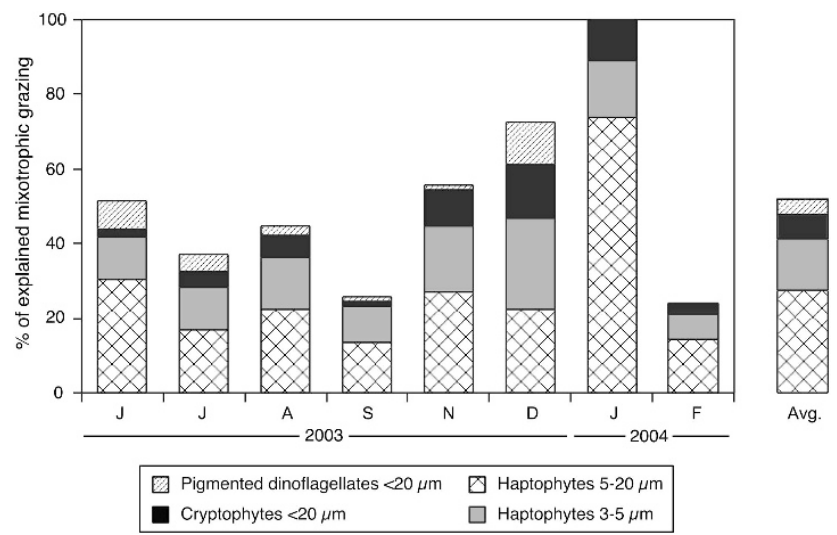

Figure 6 Percentage of grazing impact of mixotrophs on bacteria explained by each of the four investigated groups along the year. Avg., annual average.

together, did not show any significant correlation with nutrients or with the available light parameters (that is, Secchi, Kd, photoperiod).

\section{Discussion}

Pico- and nanophytoplankton composition

We were able to identify and quantify four algal groups within the $\mathrm{PF}<20 \mu \mathrm{m}$ fraction along an annual survey in the sampled oligotrophic coastal environment. Cryptophytes and pigmented dinoflagellates were exclusively nanoplanktonic organisms, whereas chlorophytes and haptophytes were observed also in the picoplankton size range.

Picoplanktonic chlorophytes cells $(<3 \mu \mathrm{m})$ were represented almost exclusively by the Prasinophyceae Micromonas pusilla. The great abundance of Micromonas is consistent with previous estimation of picoplankton composition in the Mediterranean Sea including Blanes Bay (Foulon et al., 2008) but also in other oceanic regions (for example, Not et al., 2007; 2004). Our results also revealed the existence of marked changes in the abundance of some nano-PFs $(3-20 \mu \mathrm{m})$ along the year (cryptophytes and chlorophytes dominated at the end of winter, pigmented dinoflagellates increased in summer, and at the beginning of winter all groups increased significantly), whereas haptophytes were present all year-round always at a significant number without major fluctuations (Figure 2). This result is supported by pigment analysis performed on the same time series samples (Gutiérrez-Rodríguez et al., 2011). To our knowledge, this is the first study that confirms the yearround presence of haptophytes in a marine system by direct cell counting. This year-round dominance of haptophytes was reported using dot blot hybridizations with group-specific chloroplastidic ribosomal DNA probes along a 2-year survey in the Gulf of Naples in the Mediterranean Sea (McDonald et al., 2007), in a 12-year study in the Sargasso Sea assessed by $16 \mathrm{~S}$ ribosomal RNA abundance with a T-RFLP (Terminal Restriction Fragment Length Polymorphism) approach (Treusch et al., 2012), and by analysis of accessory photosynthetic pigments across the word's ocean (Liu et al., 2009). Liu et al. (2009) observed by direct cell counting that ca $75 \%$ of haptophytes ranged between 3 and $5 \mu \mathrm{m}$, similarly as we did. Altogether, these results suggest a global spatiotemporal dominance of small flagellated haptophytes among phytoplankton in marine systems.

Haptophytes in the Mediterranean Sea are represented by different species, mostly belonging to the genus Phaeocystis, Prymnesium and Chrysochromulina (for example, Zingone et al., 1999; Puigserver et al., 2003; Vila and Masó, 2005). Although the probes we used were not specific enough to determine if species shifts occurred during the study period, some variations in the mean cell size of haptophytes were observed along the year: a higher proportion of cells $>5 \mu \mathrm{m}$ was observed in December and smaller cells were found at the end of winter. Similarly, smaller cyptophytes cells were observed during the summer-autumn 
period. A detailed analysis of the plankton from the western Mediterranean Sea (Novarino, 2005) revealed the presence of 6 different genus of cryptophytes (Chroomonas, Cryptochloris, Hemiselmis, Plagioselmis, Rhinomonas and Teleaulax) and 11 species. The variations in average cell volume here reported potentially correspond to changes in species composition during different periods of the year.

On average, we were able to assign to all investigated groups $37 \%$ of the total $\mathrm{PF}<3 \mu \mathrm{m}$ and $65 \%$ of the PF $3-20 \mu \mathrm{m}$ composition (Figure 2). Although the overall explained composition was relatively high, there was still a significant percentage that could not be assigned to any of the four algal groups assayed in our study, so additional algal groups were missed in our analyses. Similarly, in the NW Iberian coast 35\% of total picoeukaryotes could not be assigned to specific algal groups (Not et al., 2007). Besides prasinophytes, other taxa could also contribute significantly to picoeukaryotic communities. Estep et al. (1986) noticed that mixotrophic chrysophytes, a group of algae traditionally considered important in freshwaters only, could account for a significant proportion of small PFs in marine environments too. Pelagophytes have also been described as widespread marine algae (Worden et al., 2012). Recently, and combining cellsorting and TSA-FISH in the NE Atlantic Ocean, Jardillier et al. (2010) found that on average $60 \%$ of the small (average $1.8 \mu \mathrm{m}$ in size) and most abundant picoeukaryotic population in their samples included pelagophytes and chrysophytes. This was confirmed with plastid gene sequencing in the Pacific Ocean (Shi et al., 2011), and concurs with previous results of dot-blot hybridizations using class level probes based on plastid 16S ribosomal DNA sequences, in the Arabian and Mediterranean seas (Fuller et al., 2006; McDonald et al., 2007). In particular, Fuller et al. (2006) and McDonald et al. (2007) reported the highest proportion of chrysophytes in association with warmer waters, that is, indicated a preference for the summer months. Although this pattern should be confirmed with a quantitative method (that is, FISH), these results would explain the relatively high level of unexplained composition during the warmer period in Blanes Bay. The percentage of unidentified picoplanktonic organisms in our samples would be reduced by targeting more taxa using a larger set of FISH probes.

Preliminary results of 454 pyrosequencing performed on 13 samples taken at six different sites, including Blanes Bay (methodology explained in detail in Logares et al., 2012), revealed that between $10 \%$ and $15 \%$ of the retrieved sequences corresponded to algae that were not quantified in the present work: pelagophytes, chrysophytes, dictyochophytes and a novel lineage within ochrophytes. All of them are potential candidates to explain the unidentified PF composition and, interestingly, most of these groups contain known mixotrophic organisms.

\section{Mixotroph impact}

Using the approach previously published in Massana et al. (2009), we estimated here the in situ grazing rates of haptophytes by combining FLB ingestion and FISH detection and quantification. The main advantage of the FLB ingestion approach is that it allows the cell-by-cell inspection, and therefore, the estimation of grazing rates of specific groups of bacterivores (Caron, 2001). However, this approach assumes that the FLB will be consumed at rates equivalent to similarly sized, naturally occurring prey and some negative selection might occur, with consequent underestimation of the real grazing rates. In spite of this limitation, the use of FLB to examine bacterivory is a common tool widely accepted in microbial ecology (Caron, 2001). The fixative is another issue to be considered. An equal large volume of diluted glutaraldehyde in a ratio 1:1 (volume fixative: volume sample) is recommended in order to minimize egestion of FLB during fixation of samples (Sherr et al., 1989). Here, we had to use formaldehyde (also in a 1:1 ratio with the sample), as we did in previous work (Massana et al., 2009), because glutaraldehyde compromises FISH detection (Medina Sánchez et al., 2005). Although the grazing rates of haptophytes might have been underestimated, the use of diluted formaldehyde should have minimized the problem.

In this study, we identified three potentially mixotrophic groups (that is, haptophytes, cryptophytes and pigmented dinoflagellates) that were present year-round in the study site, and accounted together for $38-67 \%$ of the total PF $(<20 \mu \mathrm{m})$ biomass (Figure 3). These three phytoplankton groups explained $9-42 \%$ (average 19\%) of the total bacterivory in this system.

The haptophytes were the most important mixotrophic group, among which the intermediate size $(3-5 \mu \mathrm{m})$ was the most abundant and active bacterivore type. Their CSGRs $\left(0.2-1.8\right.$ bact. cells $\left.{ }^{-1} \mathrm{~h}^{-1}\right)$ are within the range of the few estimations performed up to the present (Supplementary Table 3), overlapping the grazing rates range of bacterivorous non-photosynthetic organisms of the same size (that is, HF $3-5 \mu \mathrm{m}=0.8-4$ bact. cells ${ }^{-1} \mathrm{~h}^{-1}$ ) estimated in Blanes Bay (Unrein et al., 2007). This highlights the importance of the heterotrophic mode of nutrition for the growth of haptophytes. The high abundance of haptophytes $3-5 \mu \mathrm{m}$ implied that, on average, they accounted for about twice the grazing impact (bact. $\mathrm{ml}^{-1} \mathrm{~h}^{-1}$ ) of the larger organisms (that is, haptophytes $5-20 \mu \mathrm{m}$ and cryptophytes). The entire group of haptophytes $(<20 \mu \mathrm{m})$ explained between $15 \%$ and $89 \%$ of the bacterivory exerted by all $\mathrm{PF}<20 \mu \mathrm{m}$ along the 1-year study (total value presented in Unrein et al., 2007), and 9-27\% of the total bacterivory exerted by all bacterivorous protists 
$<20 \mu \mathrm{m}$. If the haptophytes grazing rates were underestimated, then the haptophytes should be even more important than we estimated in the present work. Our results are in agreement with Havskum and Riemann (1996); these authors calculated that haptophytes were responsible for $76 \%$ of the total bacterivory in a 1-week summer experiment carried out in Bay of Aarhus (Denmark). Considering the wide distribution and abundance of these algae in the ocean, its relevant role as primary producers (Jardillier et al., 2010), and the significant grazing rates reported here, we can undoubtedly conclude that small haptophytes are key players in marine trophic webs.

The cryptophytes were the second most important mixotrophic group in our study. As for the haptophytes, the CR and CSGR calculated here are in the range of those estimated by other authors (Supplementary Table 3) and overlap the CSGR of $\mathrm{HF}$ estimated in the same samples (Unrein et al., 2007). Higher values have been, however, observed in freshwater environments (Supplementary Table 3). Differences in cryptophytes' grazing rates are clearly related to their cell size, that is, larger cryptophytes have higher bacterivory rates. Our results indicate that cryptophytes can account for a significant portion (up to $11 \%$ ) of the total bacterivory during the colder months, suggesting they exert a moderate impact on bacterioplankton during periods of higher cryptophyte abundance.

The cell-specific ingestion rate, expressed as percentage of the cell carbon ingested per day, was always higher for haptophytes (especially for the smaller ones) than for cryptophytes. This trend can also be observed with estimations based on published grazing rates and flagellate cell size (Supplementary Table 3). The weighted average of all estimations presented in Supplementary Table 3 is about five times higher for haptophytes than for cryptophytes $\left(6.8 \%\right.$ and $1.4 \%$ day $^{-1}$, respectively). In the case that these algae used the acquired $\mathrm{C}$ for growth, these results suggest that bacterivory would be more relevant in haptophytes than in cryptophytes. Accordingly, Tranvik et al. (1989) concluded that Cryptomonas are primary photosynthetic organisms for which phagotrophy seems not to be significant to their growth. The probable exception are cryptophytes inhabiting ice-covered lakes in Antarctica, where the heterotrophic mode of nutrition seems to prevail during the winter period (Roberts and LaybournParry, 2001; Laybourn-Parry et al., 2005; Thurman et al., 2012).

Mixotrophy among pigmented dinoflagellates has been well documented (Stoecker, 1999). The single estimate of CSGR obtained here was not negligible, but the cell-specific ingestion rate in percentage of the cell carbon ingested per day obtained from bacterial ingestion was two times lower than for haptophytes $3-5 \mu \mathrm{m}$, indicating that probably other food items (that is, algae) were more important than bacteria. Many studies highlight the herbivore role of dinoflagellates (Stoecker, 1999; and references therein), and although we did not estimate algal predation in our studies, pigmented dinoflagellates were recurrently observed with ingested haptophytes or cryptophytes (Figure 4). Dictyochophytes are also bacterial and picocyanobacterial grazers (Havskum and Riemann, 1996; Frias-Lopez et al., 2009), although the few cells of Pseudopedinella sp. observed in our samples did not allow a reliable measurement of grazing rates. Phagocytosis has been also suggested to occur in some prasinophyte flagellates, like Micromonas pusilla in seawater (Gonzalez et al., 1993), Pyramimonas gelidicola in Antarctic lakes (Bell and Laybourn-Parry, 2003) or sea-ice chlorophytes that present incorporated DAPI-stained bacteria (Piwosz et al., 2013). Definitive microscopic evidence for phagocytosis in the marine prasinophyte Cymbomonas has been recently provided by Maruyama and Kim (2013). However, in Blanes Bay neither Tetraselmis-like species nor $M$. pusilla were observed ingesting bacteria. Given that prasinophytes are important components of marine phytoplankton, these last findings highlight the need for quantitatively evaluating their contribution as bacterivores in aquatic systems.

The unexplained abundance of mixotrophs could be due to the existence of some groups not surveyed here. Considering the possibility that chrysophytes could have been missed, and taking into account the high bacterivory rates usually reported for these algae, comparables to those of purely HFs (Bird and Kalff, 1986; Nygaard and Tobiesen, 1993), chrysophytes might be responsible for a significant proportion of the total grazing impact by MFs. For instance, Dinobryon faculiferum was found at one occasion in Blanes Bay, and in spite of their very low abundance, this single species accounted for $11 \%$ of the total grazing rate exerted by all mixotrophs (Unrein et al., 2010). In addition, pelagophytes and dictyochophytes (both stramenopiles), which were present in Blanes Bay samples (see pyrosequencing data above) but not quantified here, were also potential candidates to explain part of the total bacterivory exerted by mixotrophs. Both groups are known to actively graze on picocyanobacteria (Frias-Lopez et al., 2009), and probably also on heterotrophic bacteria.

Factors controlling ingestion rates in the dominant mixotrophs

The mixotrophic strategy is expected to be successful when resources (for example, dissolved nutrients) limit strictly autotrophic growth (Rothhaupt, 1996; Flöder et al., 2006). Considering that assimilation of nutrients in particulate form is energetically more costly than absorbing them in dissolved inorganic form 
(Raven, 1997) and if phagotrophy is a way to supplement nutrients, then an inverse relationship should be expected between a given limiting nutrient and the phagotrophic activity of the mixotrophic community. We reported previously that the CSGR of PF $3-5 \mu \mathrm{m}$ and $\mathrm{PF}$ $5-20 \mu \mathrm{m}$ were both negatively significantly correlated with the soluble reactive phosphorus concentration (Unrein et al., 2007). This result suggested that MFs in Blanes Bay would be using their phagotrophic ability to obtain phosphorus from the prey when this nutrient is limiting. When looking at the same relationship, but by groups, we obtained the same good correlation between phosphorus concentration and CSGR for the cryptophytes, but not for the haptophytes. Experiments with cultures of Chrysochromulina polylepis (Nygaard and Tobiesen, 1993; Stibor and Sommer, 2003), Prymnesium patelliferum (Legrand et al., 2001) and Prymnesium parvum (Nygaard and Tobiesen, 1993) showed a decline in bacterivory activity when nutrients are plentiful, suggesting that haptophytes would utilize phagotrophy as a means to obtain limiting inorganic nutrients. Nevertheless, this prediction could not be confirmed with our in situ estimations.

The negative correlation between cryptophytes grazing rates and nutrient concentrations is in accordance with the conclusions achieved by Urabe et al. (2000) in Lake Biwa, which claimed that cryptophytes use phagotrophy as an alternative source of nutrients. Interestingly, CR and CSGR of cryptophytes in our experiments were also highly positively correlated with estimators of the in situ light condition: Secchi depth and photoperiod (defined as the number of hours of sunlight per day). This was an unexpected result since in situ light limitation is unlikely to occur in Blanes Bay (Unrein et al., 2007), and the in vitro light conditions were the same for all the experiments. One potential explanation for this observation, could be the existence of a delay in the response of these algae to the experimental conditions. Then, the time elapsed from sampling and the start of the experiment, would have probably been too short to allow the cells to adapt to the in vitro light conditions. Urabe et al. (2000) and Pålsson and Granéli (2003) observed that different species of freshwater Cryptomonas exhibited significant diurnal differences in bacterial ingestion rates, with the lowest values recorded during the night. These results suggest that phagotrophy in these organisms would be light dependent and that they might not survive using bacterivory as the unique mode of nutrition. Alternatively, freshwater Cryptomonas inhabiting Antarctic lakes seem to use mixotrophy to supplement energy when photosynthesis is limited under the ice during the polar winter (Marshall and Laybourn-Parry,
2002). These contrasting results suggest the existence of distinct strategies in the use of mixotrophy within different species of the same genus.

\section{Conflict of Interest}

The authors declare no conflict of interest.

\section{Acknowledgements}

This study was supported by EU project BASICS (EVK3-CT-2002-00078) and a post-doctoral fellowship of the former MECD (SB2001-0166). It was also partially funded by MEC projects ESTRAMAR (CTM2004-12631/MAR), GEN $\mu M A R$ (CTM2004-02586/ MAR) and FLAME (CGL2010-16304, MICINN), and by the Spanish-Argentina project PROBA (2007AR0018, CSIC). FN was supported by the Marie-Curie fellowship ESUMAST (MEIF-CT-2005-025000). We thank Vanessa Balagué for her help with field work.

\section{References}

Alonso-Sáez L, Vázquez-Domínguez E, Cardelús C, Pinhassi J, Sala MM, Lekunberri I et al. (2008). Factors controlling the year-round variability in carbon flux through bacteria in a coastal marine system. Ecosystems 11: 397-409.

Bell EM, Laybourn-Parry J. (2003). Mixotrophy in the antarctic phytoflagellate, Pyramimonas gelidicola (Chlorophyta: Prasinophyceae). J Phycol 39: 644-649.

Bielewicz S, Bell E, Kong W, Friedberg I, Priscu JC, Morgan-Kiss RM. (2011). Protist diversity in a permanently ice-covered Antarctic Lake during the polar night transition. ISME J 5: 1559-1564.

Bird DF, Kalff J. (1986). Bacterial grazing by planktonic lake algae. Science 231: 493-495.

Caron DA. (2001). Protistan herbivory and bacterivory. In: Paul J (ed.) Marine Microbiology, Vol. 30, Methods in Microbiology. Academic Press: London, pp 289-315.

Chan Y-F, Tsai A-Y, Chiang K-P, Hsieh C-H. (2009). Pigmented nanoflagellates grazing on Synechococcus: seasonal variations and effect of flagellate size in the coastal ecosystem of Subtropical Western Pacific. Microbial Ecol 58: 548-557.

Cuvelier ML, Allen AE, Monier A, McCrow JP, Messié M, Tringe SG et al. (2010). Targeted metagenomics and ecology of globally important uncultured eukaryotic phytoplankton. Proc Natl Acad Sci USA 107: 14679-14684.

Estep KW, Davis PG, Keller MD, Sieburth JM. (1986). How important are oceanic algal nanoflagellates in bacterivory? Limnol Oceanogr 31: 646-650.

Flöder S, Hansen T, Ptacnik R. (2006). Energy-dependent bacterivory in Ochromonas minima-A strategy promoting the use of substitutable resources and survival at insufficient light supply. Protist 157: 291-302.

Foulon E, Not F, Jalabert F, Cariou T, Massana R, Simon N. (2008). Ecological niche partitioning in the picoplanktonic green alga Micromonas pusilla: evidence from 
environmental surveys using phylogenetic probes. Environmental Microbiol 10: 2433-2443.

Frias-Lopez J, Thompson A, Waldbauer J, Chisholm SW. (2009). Use of stable isotope-labelled cells to identify active grazers of picocyanobacteria in ocean surface waters. Environmental Microbiol 11: 512-525.

Fuller NJ, Tarran GA, Cummings DG, Woodward EMS, Orcutt KM, Yallop M et al. (2006). Molecular analysis of photosynthetic picoeukaryote community structure along an Arabian Sea transect. Limnol Oceanogr 51: 2502-2514.

Gasol JM, del Giorgio PA. (2000). Using flow cytometry for counting natural planktonic bacteria and understanding the structure of planktonic bacterial communities. Scientia Marina 64: 197-224.

Gasol JM, Pinhassi J, Alonso-Sáez L, Ducklow H, Herndl GJ, Koblízek M et al. (2008). Towards a better understanding of microbial carbon flux in the sea. Aquat Microbial Ecol 53: 21-38.

Gonzalez JM, Sherr BF, Sherr E. (1993). Digestive enzyme activity as a quantitative measure of protistan grazing: the acid lysozyme assay for bacterivory. Mar Ecol Prog Ser 100: 197-206.

Gutiérrez-Rodríguez A, Latasa M, Scharek R, Massana R, Vila G, Gasol JM. (2011). Growth and grazing rate dynamics of major phytoplankton groups in an oligotrophic coastal site. Estuarine Coastal Shelf Sci 95: $77-87$.

Hartmann M, Grob C, Tarran GA, Martin AP, Burkill PH, Scanlan DJ et al. (2012). Mixotrophic basis of Atlantic oligotrophic ecosystems. Proc Natl Acad Sci USA 109: 5756-5760.

Havskum H, Riemann B. (1996). Ecological importance of bacterivorous, pigmented flagellates (mixotrophs) in the Bay of Aarhus, Denmark. Mar Ecol Prog Ser 137: 251-263.

Hitchman RB, Jones HL. (2000). The role of mixotrophic protists in the population dynamics of the microbial food web in a small artificial pond. Freshwater Biol 43: 231-241.

Jardillier L, Zubkov MV, Pearman J, Scanlan DJ. (2010). Significant $\mathrm{CO}_{2}$ fixation by small prymnesiophytes in the subtropical and tropical northeast Atlantic Ocean. ISME J 4: 1180-1192.

Kong W, Ream DC, Priscu JC, Morgan-Kiss RM. (2012). Diversity and expression of RubisCO genes in a perennially ice-covered Antarctic lake during the polar night transition. Apply Environ Microbiol 78: 4358-4366.

Laybourn-Parry J, Marshall WA, Marchant HJ. (2005). Flagellate nutritional versatility as a key to survival in Antarctic phytoflagellates in two contrasting saline lakes. Freshwater Biol 50: 830-838.

Legrand C, Johansson N, Johnsen G, Borsheim KY, Granéli E. (2001). Phagotrophy and toxicity variation in the mixotrophic Prymnesium patelliferum (Haptophyceae). Limnol Oceanogr 46: 1208-1214.

Liu H, Probert I, Uitz J, Claustre H, Aris-Brosou S, Frada $\mathrm{M}$ et al. (2009). Extreme diversity in noncalcifying haptophytes explains a major pigment paradox in open oceans. Proc Natl Acad Sci 106: 12803-12808.

Logares R, Audic S, Santini S, Pernice MC, de Vargas C, Massana R. (2012). Diversity patterns and activity of uncultured marine heterotrophic flagellates unveiled with pyrosequencing. ISME J 6: 1823-1833.

MacIsaac EA, Stoeckner JG. (1993). Enumeration of phototrophic picoplankton by autofluorescence microscopy. In: Kemp PF, Sherr BF, Sherr EB Cole JJ (eds.) Handbook of methods in Aquatic Microbial Ecology, Vol 30. Lewis Publishers: Boca Raton, Florida, USA, pp 187-197.

Marshall WA, Laybourn-Parry J. (2002). The balance between photosynthesis and grazing in Antarctic mixotrophic cryptophytes during summer. Freshwater Biol 47: 2060-2070.

Maruyama S, Kim E. (2013). A modern descendant of early green algal phagotrophs. Curr Biol 23: 1081-1084.

Massana R, Terrado R, Forn I, Lovejoy C, Pedrós Alió C. (2006). Distribution and abundance of uncultured heterotrophic flagellates in the world oceans. Environ Microbiol 8: 1515-1522.

Massana R, Unrein F, Rodríguez-Martínez R, Forn I, Lefort T, Pinhassi J et al. (2009). Grazing rates and functional diversity of uncultured heterotrophic flagellates. ISME J 3: 588-596.

McDonald SM, Sarno D, Scanlan DJ, Zingone A. (2007). Genetic diversity of eukaryotic ultraphytoplankton in the Gulf of Naples during an annual cycle. Aquat Microbial Ecol 50: 75-89.

Medina Sánchez JM, Felip M, Casamayor EO. (2005). Catalyzed reported deposition-fluorescence in situ hybridization protocol to evaluate phagotrophy in mixotrophic protists. Appl Environ Microbiol 71: 7321-7326.

Menden-Deuer S, Lessard EJ. (2000). Carbon to volume relationships for dinoflagellates, diatoms, and other protist plankton. Limnol Oceanogr 45: 569-579.

Norland S. (1993). The relationship between biomass and volume of bacteria. In: Lewis (eds). Handbook of Methods in Aquatic Microbial Ecology. Lewis Publishers: Boca Raton, pp 303-307.

Not F, Latasa M, Marie D, Cariou T, Vaulot D, Simon N. (2004). A single species, Micromonas pusilla (Prasinophyceae), dominates the eukaryotic picoplankton in the western English Channel. Appl Environ Microbiol 70: 4064-4072.

Not F, Simon N, Biegala IC, Vaulot D. (2002). Application of fluorescent in situ hybridization coupled with tyramide signal amplification (FISH-TSA) to assess eukaryotic picoplankton composition. Aquat Microbial Ecol 28: 157-166.

Not F, Zapata M, Pazos Y, Campaña E, Doval M, Rodríguez F. (2007). Size-fractionated phytoplankton diversity in the NW Iberian coast: a combination of microscopic, pigment and molecular analyses. Aquat Microbial Ecol 49: 255-265.

Novarino G. (2005). Nanoplankton protists from the western Mediterranean Sea. II. Cryptomonads (Cryptophyceae $=$ Cryptomonadea). Scientia Marina 69: $47-74$.

Nygaard K, Tobiesen A. (1993). Bacterivory in algae: a survival strategy during nutrient limitation. Limnol Oceanogr 38: 273-279.

Pernthaler J, Glöckner F-O, Schönhuber W, Amann R. (2001). Fluorescence in situ hybridization (FISH) with rRNA-targeted oligonucleotide probes. Methods Microbiol 30: 207-226.

Piwosz K, Wiktor JM, Niemi A, Tatarek A, Michel C. (2013). Mesoscale distribution and functional diversity of picoeukaryotes in the first-year sea ice of the Canadian Arctic. ISME J 7: 1461-1471.

Porter KG, Feig YS. (1980). The use of DAPI for identifying and counting aquatic microflora. Limnol Oceanogr 25: 943-948. 
Puigserver M, Chrétiennot-Dinet M-J, Nezan E. (2003). Some Prymnesiaceae (Haptophyta, Prymnesiophyceae) from the Mediterranean Sea, with the description of two new species: Chrysochromulina lanceolata sp. nov. and C. pseudolanceolata sp. nov. J Phycol 39: 762-774.

Pålsson C, Granéli W. (2003). Diurnal and seasonal variations in grazing by bacterivorous mixotrophs in an oligotrophic clearwater lake. Archiv für Hydrobiologie 157: 289-307.

Raven JA. (1997). Phagotrophy in phototrophs. Limnol Oceanogr 42: 198-205.

Rice JA. (1988). Mathematical statistics and data analysis. The Wadsworth \& Brooks/Cole Statistics/Probability Series. Wadsworth \& Brooks: Pacific Grove, CA, USA.

Roberts EC, Laybourn-Parry J. (2001). Mixotrophic cryptophytes and their predators in the Dry Valley lakes of Antarctica. Freshwater Biol 41: 737-746.

Rothhaupt KO. (1996). Laboratorary experiments with a mixotrophic chrysophyte and obligately phagotrophic and photographic competitors. Ecology 77: 716-724.

Sanders RW. (1991). Mixotrophic protists in marine and freshwater ecosystems. J Protozool 38: 76-81.

Sanders RW, Porter KG, Bennett SJ, DeBiase AE. (1989). Seasonal patterns of bacterivory by flagellates, ciliates, rotifers, and cladocerans in a freshwater planktonic community. Limnol Oceanogr 34: 673-687.

Schauer M, Balagué V, Pedrós Alió C, Massana R. (2003). Seasonal changes in the taxonomic composition of bacterioplankton in a coastal oligotrophic system. Aquat Microbial Ecol 31: 163-174.

Sherr BF, Sherr EB, Fallon RD. (1987). Use of monodispersed fluorescently labeled bacteria to estimate in situ protozoan bacterivory. Appl Environ Microbiol 53: 958-965.

Sherr BF, Sherr EB, Pedrós-Alió C. (1989). Simultaneous measurement of bacterioplankton production and protozoan bacterivory in estuary waters. Mar Ecol Prog Ser 54: 209-219.

Shi XL, Lepère C, Scanlan DJ, Vaulot D. (2011). Plastid 16S rRNA gene diversity among eukaryotic picophytoplankton sorted by flow cytometry from the South Pacific Ocean. PLoS One 6: e18979.

Simon M, Azam F. (1989). Protein content and protein synthesis rates of planktonic marine bacteria. Mar Ecol Prog Ser 51: 201-213.

Simon N, Campbell L, Örnólfsdottir E, Groben R, Guillou L, Lange M et al. (2000). Oligonucleotide probes for the identification of three algal groups by dot blot and fluorescent whole-cell hybridization. J Eukaryotic Microbiol 47: 76-84.

Stibor H, Sommer U. (2003). Mixotrophy of a photosynthetic flagellate viewed from an optimal foraging perspective. Protist 154: 91-98.

Stoecker DK. (1999). Mixotrophy among Dinoflagellates. J Eukaryotic Microbiol 46: 397-401.
Sun J, Liu D. (2003). Geometric models for calculating cell biovolume and surface area for phytoplankton. J Plankton Res 25: 1331-1346.

Thurman J, Parry J, Hill PJ, Priscu JC, Vick TJ, Chiuchiolo A et al. (2012). Microbial dynamics and flagellate grazing during transition to winter in Lakes Hoare and Bonney, Antarctica. FEMS Microbiol Ecol 82: 449-458.

Tranvik LJ, Porter KG, Sieburth JM. (1989). Occurrence of bacterivory in Cryptomonas, a common freshwater phytoplankter. Oecologia 78: 473-476.

Treusch AH, Demir-Hilton E, Vergin KL, Worden AZ, Carlson CA, Donatz MG et al. (2012). Phytoplankton distribution patterns in the northwestern Sargasso Sea revealed by small subunit rRNA genes from plastids. ISME J 6: 481-492.

Tsai AY, Gong GC, Sanders RW, Chen WH, Chao CF, Chiang KP. (2011). Importance of bacterivory by pigmented and heterotrophic nanoflagellates during the warm season in a subtropical western Pacific coastal ecosystem. Aquat Microbial Ecol 63: 9-18.

Unrein F, Gasol JM, Massana R. (2010). Dinobryon faculiferum (Chrysophyta) in coastal Mediterranean seawater: presence and grazing impact on bacteria. J Plankton Res 32: 559-564.

Unrein F, Massana R, Alonso-Sáez L, Gasol JM. (2007). Significant year-round effect of small mixotrophic flagellates on bacterioplankton in an oligotrophic coastal system. Limnol Oceanogr 52: 456-469.

Urabe J, Gurung TB, Yoshida T, Sekino T, Nakanishi M, Maruo M et al. (2000). Diel changes in phagotrophy by Cryptomonas in Lake Biwa. Limnol Oceanogr 45: 1558-1563.

Vila M, Masó M. (2005). Phytoplankton functional groups and harmful algal species in anthropogenically impacted waters of the NW Mediterranean Sea. Scientia Marina 69: 31-45.

Vázquez-Domínguez E, Vaqué D, Gasol JM. (2007). Ocean warming enhances respiration and carbon demand of coastal microbial plankton. Global Change Biol 13: 1327-1334.

Worden AZ, Janouskovec J, McRose D, Engman A, Welsh RM, Malfatti S et al. (2012). Global distribution of a wild alga revealed by targeted metagenomics Curr Biol 22: 675-677.

Zingone A, Chrétiennot-Dinet M-J, Lange M, Medlin L. (1999). Morphological and genetic characterization of Phaeocystis cordata and P. jahnii (Prymnesiophyceae), two new species from the Mediterranean Sea. J Phycol 35: 1322-1337.

Zubkov MV, Tarran GA. (2008). High bacterivory by the smallest phytoplankton in the North Atlantic Ocean. Nature 455: 224-226.

Zubkov MV, Zöllner E, Jürgens K. (2001). Digestion of bacterial macromolecules by a mixotrophic flagellate, Ochromonas sp., compared with that by two heterotrophic flagellates, Spumella pudica and Bodo saltans. Eur J Protistol 37: 155-166.

Supplementary Information accompanies this paper on The ISME Journal website (http://www.nature.com/ismej) 